\title{
DATABASES TO SUPPORT ASSET MANAGEMENT AND SOCIAL REUSE: THE CASE STUDY OF THE REPUBLIC OF NORTH MACEDONIA
}

\author{
Barbara Vettori, PhD, Assistant Professor \\ Faculty of Political and Social Sciences, Catholic University of Milan \\ Largo A. Gemelli, 1 - 20123 Milano, Italy \\ barbara.vettori@unicatt.it ${ }^{1}$
}

Boban Misoski, PhD, Associate Professor

Faculty of Law "Iustinianus Primus" of the University Ss. Ciryl and Methodius Skopje

Goce Delchev, No. 9 B, Skopje, Republic of North Macedonia

b.misoski@pf.ukim.edu.mk ${ }^{2}$

\begin{abstract}
Over the past decades, many EU and non EU countries have amended their legislative and institutional framework on proceeds of crime confiscation to deprive criminals of their assets more effectively and to better manage and dispose of them. There are still, however, some underresearched issues that could greatly enhance the effectiveness and efficiency of confiscation policies. A first topic is the contribution that databases can give to asset management and disposal; the second one deals with a particular asset disposal option which involves giving criminal proceeds back to the communities affected by crime and promoting their use in line with communal needs: social reuse. This article responds to this question: what is the current situation regarding these two key issues in the Republic of North Macedonia?
\end{abstract}

Keywords: databases on seized and confiscated assets, disposal of confiscated assets, social reuse, EU, Republic of North Macedonia.

\footnotetext{
1 Barbara Vettori is author of the following sections of this article: 1, 2 and 3.

2 Boban Misoski is author of the following sections of this article: 4 and 5 .
} 


\section{INTRODUCTION}

Over the past decades, supranational standards $s^{3}$ have been developed on seizure and confiscation, with a view to increase the efficiency of asset management and disposal. ${ }^{4}$ Many countries have set up Asset Management Offices (AMOs), to ensure the adequate management of seized and provisionally confiscated assets pending judicial proceedings. However, there has been so far little discussion about two key mechanisms in this respect, namely:

1) how ICT (Information and Communication Technology) tools can support asset management and disposal: the better one knows the assets, the better they can be managed. Still, very little attention has been paid so far to how the structured and regular collection of data on seized and confiscated assets in a database can boost confiscation policies;

2) how the benefits from confiscation policies can be made visible to citizens and shares with the communities affected by crime: different forms of reuse of confiscated assets are possible. In addition to the traditional transfer of ill-gotten gains into the State budget, some Member States envisage an innovative form of disposal that is attracting increasing attention at the EU level: the reuse of confiscated assets for social purposes.

This article answers the following question: what is the current situation regarding these two key issues in the Republic of North Macedonia?

3 See, for example, the 2010 Justice and Home Affairs Council Conclusions on confiscation and asset recovery and the 2010 Commission Communication on an EU Internal Security Strategy (COM(2010) 673 final). Also Directive 2014/42/EU deals with the topic. Article 7 requires Member States to take "the necessary measures to enable the freezing of property with a view to possible subsequent confiscation. Those measures [...] shall include urgent action to be taken when necessary in order to preserve property". Article 10 invites Member States to take the measures necessary to ensure the adequate management of property frozen with a view to possible subsequent confiscation, including the establishment of centralised offices/a set of specialised offices/equivalent mechanisms, as well as the possibility to sell or transfer property where necessary. Also the Financial Action Task Force (FATF) recommended countries to implement a program for efficiently managing frozen property and, where necessary, disposing of it. See FATF, Best Practices Paper. Best practices on confiscation (recommendations 4 and 38) and a framework for ongoing work on asset recovery, FATF/OECD, Paris, October 2012, pp. 9-10.

4 At the end of any judicial procedure aimed at removing the proceeds from crime, the issue of what to do with them arises. These issues are dealt with in the disposal phase, which is the phase in which a final confiscation order is enforced and confiscated assets are disposed of. 


\section{DATABASES TO SUPPORT ASSET MANAGEMENT: THE DEBATE AT THE INTERNATIONAL LEVEL}

Notwithstanding the establishment of AMOs in many EU and non EU countries, ${ }^{5}$ "there have been few instructions on how they should collect and manage data" ${ }^{6}$

The first institution taking a position on this issue was, in 2005, the Criminal Legal Affairs working group of the G8, that suggested that: "States should consider the use of information technology (IT) systems for the administration of seized property. Appropriate financial and property administration IT systems can, for example, be extremely useful for tracking and managing inventory or for meeting expenses associated with seized property as well as for maintaining a transparent and accountable system. States may also wish to use such IT systems for the administration of confiscated property".

The Camden Asset Recovery Inter-agency Network (CARIN), which is an informal network of law enforcement and judicial practitioners in the field of asset tracing, freezing, seizure and confiscation, also regards databases as a key tool. The recommendations of the 2008 CARIN General Assembly on "Promoting the Creation of National Asset Recovery Offices and the Effective Management of Seized and Confiscated Assets" stressed, in respect to AMOs, the importance of establishing a centralized database to track all assets seized or restrained for confiscation.

In 2011 the Organización de los Estados Americanos (OAS) also dealt with registries of seized and forfeited property and stated that "States should consider using software to maintain a registry of seized and forfeited assets, sometimes called Asset Management Systems (AMS). This technological tool will be used to record income, transfers, judicial proceedings, legal situation, identification of objects, and the location of each asset in custody, in order to permit quick verification of its current status. An AMS also will permit the generation of reports on the amount

According to a recent report by the European Commission, "13 Member States (Belgium, Bulgaria, Czechia, Ireland, Greece, Spain, France, Croatia, Italy, Luxembourg, Netherlands, Portugal, Romania) have set up, or are in the process of setting up, Asset Management Offices (AMOs) to ensure the management of frozen property in order to preserve its economic value". See European Commission, Report from the Commission to the European Parliament and the Council - Asset recovery and confiscation: Ensuring that crime does not pay, Brussels, 2 June 2020, p. 12, COM(2020) 217 final, available at [https://ec.europa.eu/home-affairs/sites/default/files/what-we-do/policies/european-agenda-security/20200602_com-2020-217-commission-report_en.pdf], Accessed 10 June 2021.

6 Organización de los Estados Americanos, Analysis of Systems for the Collection of Data on Seized and Forfeited Assets of Illicit Origin in the Member States of the OAS, 2014, p. 8, available at [http://cicad. oas.org/apps/document.aspx?id=2978], Accessed 10 June 2021.

7 G8 Lyon/Roma Group Criminal Legal Affairs Subgroup, G8 Best Practices for the Administration of Seized Assets, 27 April 2005, p. 3. 
of real estate and personal property, as well as the preparation of statistics on assets seized and forfeited, accountability, management costs, and financial statements. It also seeks to promote transparency and good governance in management of seized and forfeited assets, because the data recorded in the system will be subject to public scrutiny". ${ }^{8}$ OAS clearly identified the three different types of benefits brought about by these systems, i.e. support to asset management activities, statistical production and promotion of transparency/accountability of the whole management process. In 2014, OAS developed some detailed recommendations in this field, that are herein summed up:

- information should be collected by a centralized agency and in a centralized, customized, structured database;

- all agencies involved in confiscation proceedings (from investigation to disposal) should input data;

- information shall be updated by specialized personnel, and the ability to change information in the database should be granted only to authorized personnel;

- for each asset a description should be available, as well as information on its physical location, owner, condition and value at the time of seizure; also, a serial number should be attributed to each asset when taken into custody;

- the updated total number of assets, total number of assets by description and by category should be publicly available. ${ }^{9}$

The setting up of dedicated databases is also recommended, at the EU level, in the report of the ARO (Asset Recovery Offices) Sub-group on Asset Management, set up in 2013 within the ARO Platform.

The topic has more recently been dealt with by UNODC, that in 2017 recognised that "in the early stages of developing asset management capacity, countries have developed fairly rudimentary data-capturing and data-storage mechanisms. As the system matures, it becomes harder to maintain accurate record of all property subject to seizure and confiscation orders. The need to improve or develop ever-more sophisticated capacity to maintain, access and keep the data reliable and secure

8 Organización de los Estados Americanos, Asset Management Systems in Latin America and Best Practices Document on Management of Seized and Forfeited Assets, 2011, p. 127, available at [http://www.cicad. oas.org/lavado_activos/grupoExpertos/Decomiso\%20y\%20ED/Manual\%20Bienes\%20Decomisados\%20-\%20BIDAL.pdf], Accessed 10 June 2021.

9 Organización de los Estados Americanos, Analysis of Systems for the Collection of Data on Seized and Forfeited Assets of Illicit Origin in the Member States of the OAS, 2014, pp. 38-40. 
increases". ${ }^{10}$ As a result, UNODC suggested to promote further discussion on the topic of electronic databases to improve information management on restrained and confiscated property, with a special focus on good practices in this field. ${ }^{11}$

\section{SOCIAL REUSE: DEFINITION AND KEY EXPERIENCES WITHIN THE EU}

The second key topic addressed by the article is social reuse of confiscated assets. Social reuse involves giving the criminal proceeds back to the communities affected by (organised) crime and promoting their use in line with communal needs. Its attractiveness is the visibility of confiscated assets among citizens.

According to the findings of the EU-funded Study RECAST, sale is the main disposal option in practically all Member States. ${ }^{12}$ However, about two-thirds of Member States envisage, though almost never as first choice, different forms of reuse of the assets/proceeds, via their transfer to state/local institutions ('institutional reuse', via incentivisation schemes) or to society/non-government organisations (NGOs) ('social reuse').

The key social reuse experiences within the EU are in Belgium, France, Hungary, Italy, Luxembourg, Scotland and Spain. These experiences fit one of two models: direct and indirect social reuse. Direct reuse operates in Italy, Belgium (Flemish region), and Hungary. Assets are reassigned for the public benefit through a change in their intended use (e.g. conversion of the house formerly belonging to a criminal boss into a playgroup). Indirect social reuse is where the proceeds of crime (or from the sale of confiscated assets) are distributed via specialised funds that use them either a) in crime prevention projects or b) in incentivisation schemes for law enforcement agencies, so that these entities may have a further incentive to

10 UNODC, Effective management and disposal of seized and confiscated assets, UNODC, Vienna, 2017, p. 59, available at [https://www.unodc.org/documents/corruption/Publications/2017/17-07000_ebook_sr.pdf], Accessed 10 June 2021.

11 UNODC, Effective management and disposal of seized and confiscated assets, UNODC, Vienna, 2017, p. 67.

12 The Study was awarded to the Department of European Studies and International Integration at the University of Palermo by the European Commission, DG HOME under the 2010 ISEC Programme. It was carried out in the period November 2011-November 2014 in co-operation with the Center for the Study of Democracy and the FLARE Network, and with the support of Agenzia nazionale per l'amministrazione e la destinazione dei beni sequestrati e confiscati alla criminalità organizzata and UNICRI. Its aim was to promote the development of common European standards on the reuse of confiscated assets for social purposes. See Vettori, B., "The disposal of confiscated assets in the EU Member States: what works, what does not work and what is promising", in King, C.; Walker, C.; Gurulé, J. (eds.), The Palgrave handbook of criminal and terrorism financing law, volume 1, Palgrave Macmillan, Basingstoke, 2018, pp. 705-733. 
keep on fighting crime - always, even if indirectly, in the interest of society. Under this mechanism confiscated assets are not straightforwardly passed on to society, rather the proceeds from their sale are. In addition, the proceeds may not always be reused for the immediate, but rather mediate (via incentivisation schemes) interest of society. This model is in place in France, Spain, ${ }^{13}$ Luxembourg and Scotland.

\section{DATABASES TO SUPPORT ASSET MANAGEMENT IN THE REPUBLIC OF NORTH MACEDONIA}

As part of several multinational networks for managing confiscated assets, such as BAMIN network, ${ }^{14}$ the Republic of North Macedonia is taking direct steps to introduce the novelties that are present in this field into its national jurisdiction. This means that the Macedonian system is eagerly trying to update its legal framework to the latest EU trends, in particular by establishing the Asset Recovery Office and a database registry supporting asset management. At the moment, these trends have been followed through the drafting of a Law on Asset Recovery Office and the introduction of elaborate reforms into the Law on Management of Confiscated Assets, ${ }^{15}$ where one particular amendment is the setting up of a database for tracking confiscated assets as a tool for their effective and efficient management by the Macedonian Asset Management Office.

\section{POTENTIAL FOR ADOPTION OF SOCIAL REUSE IN THE REPUBLIC OF NORTH MACEDONIA}

\subsection{Disposing of the proceeds from crime in Macedonia: law in the books, law in action}

Current legal framework. The Law on Management of Forfeited Property, Proceeds and Seized Items in Criminal and Misdemeanour Proceedings (further in the text Law on Management of Confiscated Assets) regulates the disposal of assets confiscated within criminal proceedings in the Republic of North Macedonia. This

13 The Spanish model envisages both direct and indirect social reuse. In practice the second option is predominantly used.

14 See [http://www.bamin-network.org/], Accessed 10 June 2021.

15 Currently, the two working groups established by the Ministry of Justice have provided a Draft Law on Asset Recovery Office and amendments to the Law on Assets Management where establishing of a database is envisioned. Considering the State's Strategy for Reform of the National Legislation, these two laws should be enacted by the Parliament by the end of 2021 . 
Law on Management of Confiscated Assets was enacted in 2008 and has been amended several times since then. ${ }^{16}$

The Law on Management of Confiscated Assets regulates the establishment, operation and status of the Agency for the Management of Seized and Confiscated Property (further in the text Agency), together with the procedure for management and disposal of seized and confiscated assets. This law establishes three disposal options for confiscated assets. Furthermore, the Law on Management of Confiscated Assets regulates the activities of the Agency in regard to the management of the frozen assets, providing opportunities for early sale of such assets in order to protect such frozen assets during the course of the criminal proceedings.

In regard to the disposal of the confiscated assets it seems that the Macedonian Law on Management of Confiscated Assets does not recognize the possibility for direct social reuse of the confiscated assets. Explained in a nut shell, the first, and most commonly used, possibility for disposal of the confiscated assets is sale. This procedure is regulated within the articles 33 to 50 of the Law on Management of Confiscated Assets. ${ }^{17}$ Hence, confiscated assets are sold on public bids organized by the Agency, except for gold which is transferred to the National Bank. The money gathered from the assets sold on public bids is considered as income to the State budget and the Law on Management of Confiscated Assets does not contain any provisions for possible structural and specific allocation of this income to specific state agencies. Unfortunately, the Law on Management of Confiscated Assets does not recognize possibility for other types of disposal of such assets besides the public bid. Hence forward, the Law on Management of Confiscated Assets does not provide sufficient legal basis for effective legitimation for the biding procedure. This means that it does not contain detailed provisions in regard to the effective limitation of the persons connected to the defendant's from whom the assets has been confiscated. In addition, the Law on Management of Confiscated Assets does not contains provisions for limiting the possibility from excessive or non-realistic biddings which later would significantly increase the value of the bidding assets, that will finally leads to the situation where the winner of the bidding procedure would not pay the bidding price and by such action would undermine the opportunity for selling of the confiscated assets.

The second possibility for disposal of the confiscated assets is the direct transfer of confiscated assets to the Government or to state bodies and agencies, as regulated

\footnotetext{
16 Official Gazette of the Republic of Macedonia No. 98/2008, 145/2010, 104/2013, 187/2013, 43/2014, 160/2014, 97/2015, 148/2015 and 64/2018.

17 Ibid.
} 
in articles 51 and 52 of the Law on Management of Confiscated Assets. ${ }^{18}$ Within these provisions of the Law on Management of Confiscated Assets it is regulated that confiscated assets can be transferred to the Government and/or its bodies, local municipalities, state institutions, state agencies, and other agencies, funds and directorates established by the State ${ }^{19}$, without any financial contribution. This means that in such cases the confiscated asset is simply transferred to the state institutions without any purchase. In both of such options for disposal the decision for disposal is performed by the Agency upon prior approval from the Government of the Republic of North Macedonia.

Finally, confiscated assets may be rented to third parties, as regulated in the article $38-\mathrm{a}^{20}$ of this Law, limiting this possibility for renting it to the defendants from whom the asset has been confiscated. The rent will be also considered as an income to the State budget and transferred to the State budget.

Bearing on mind these provisions it is apparent that the most common or even dominant way of disposal of confiscated assets in Republic of North Macedonia is selling trough public bid. Henceforward, despite the fact that there is possibility for transfer of confiscated assets to the state bodies and institutions, it is not clearly stated that this transfer is purposed for social reuse of the confiscated assets. Furthermore, the Law on Management of Confiscated Assets does not provide provisions stating the purpose of the further use of the confiscated assets when they are transferred to the state bodies. Unfortunately, the Law on Management of Confiscated Assets does not allow the possibility for transfer of these goods to NGO's or other non-profit organizations as part of its social use opportunity.

As addition to the legal imperfection, we can state the absence of the provisions in the Law on Management of Confiscated Assets which would regulate the possibility for transfer of part of the money received from the selling of the confiscated assets to the Agency as direct benefit from its activities in regard to the management of the confiscated assets.

Law in practice. When analysing the practical implementation of the confiscation and freezing of the property, proceeds and instrumentalities which have derived from crimes in the Republic of North Macedonia one must state that confiscation appears relatively rare in the practice by the Macedonian courts ${ }^{21}$. Such small num-

\footnotetext{
18 Ibid.

19 As regulated in the Article 52 of the Law on Management of Confiscated Assets.

20 Ibid.

21 See the annual reports from these State bodies available at [www.stat.gov.mk] and [www.odzemenimot.gov.mk] See the annual report of the biggest Criminal Court in the Republic of Macedonia,
} 
ber of confiscations performed by the national courts may be based upon several factors, where one of the most influential might be the poor financial investigation of the assets during the pre-trial phase. This means that in most of the cases the financial investigations are absent or rarely simultaneously led during the criminal investigation as an initial phase of the criminal procedure. ${ }^{22}$ Due to these reasons, in most of the cases judges do not have sufficient information regarding the defendant's assets, and do not have proper evidence in regard of the real owners of the assets that should be confiscated. ${ }^{23}$ Such environment produces the low number of confiscated assets and generates the court practice where the judges, in most cases, stick only to forfeiture of the instrumentalities of the crime (corpora delicti) as one of the most undisputed assets that can be forfeited from the defendants.

In regard to the tracking of the number of the actual assets that were confiscated by the Macedonian courts, it seems that there are several problematic areas which mask the real number and the worth of the assets. Difficulties of the determining of the real number and types of assets that are confiscated are due to the fact that there are discrepancies between the publicly available reports depending on the issuing agency. This means that the numbers of the actual confiscations do not correlate between each other, considering the numbers gathered from the courts, state statistical bureau, or the Agency for managing of the confiscated assets. ${ }^{24}$

Additional reason for such differences of the data rests upon the fact that data gathered from the courts in most of the cases consists data of the confiscated assets mixed with the data for forfeited instrumentalities of the crime (corpora delicti). ${ }^{25}$

Basic Criminal Court in Skopje, available at [http://www.vsrm.mk/wps/portal/osskopje1/], Accessed 10 June 2021.

22 Understaffing has been constantly reported as important challenge in the functioning of the Public Prosecution Offices. See Yearly Reports of the Public Prosecution, available at: Годишен извештај за работата на јавните обвинителства во Република Северна Македонија за 2019 година ЈАВНО ОБВИНИТЕЛСТВО НА РЕПУБЛИКА СЕВЕРНА МАКЕДОНИЈА, [jorm.gov.mk]. Also see: Conclusions from the round table regarding the Practical implementation of Confiscation, 08.06.2018, conducted by Network 23+, available at [http://www.merc.org.mk/aktivnost/48/dijalog-za-politika-konfiskacija-na-imot-i-nelegalno-steknata-imotna-korist], Accessed 10 June 2021.

23 See: Misoski, B.; Petrovska, N.; Avramovski D., Analysis of Data Obtained from Monitoring Court Proceedings within the Field of Organized Crime and Corruption in 2019, "Coalition All for Fair Trials", OSCE Mission to Skopje, 2020.

24 See: Misoski B., The Impact of the EU Directive 2014/42/EU on Freezing and Confiscation of Instrumentalities and Proceeds of Crime to the Macedonian Criminal Justice System, in: Petrašević, T.; Duić, D. (eds.), EU Law in Context - Adjustment to Membership and Challenges of the Enlargement, Vol. 2, Faculty of Law Osijek, Croatia, 2018, also see the annual reports from these State bodies available at [www.stat.gov.mk] and [www.odzemenimot.gov.mk], Accessed 10 June 2021.

25 See: Avramovski D.; Petrovska N., Confiscation of Assets in the Corruption Cases, CAFT, 2019 (in Macedonian), available at: [PB-CAFT-MKD-2019.pdf], [all4fairtrials.org.mk], Accessed 10 June 2021. 
Disregarding the fact that there are methodological discrepancies between the data gathering and data reporting regarding the number of the court cases where the assets have been confiscated, it is interesting to understand what the epilogue of such confiscated assets is. Furthermore, despite the fact that the number of such cases is relatively low, it is still and intriguing question what does Macedonian authorities do with such assets.

For answering of this issue, the most accurate data in regard to the future resolution of the confiscated assets can be considered the data gathered from the Agency. However, unfortunately the Agency does not provide detailed yearly report that is available on their official web site. Hence, it is not easy to correlate the court performance in regards to the confiscation and the epilogue of the confiscated assets, since the court proceedings are rather lengthy, and on top of this the procedure itself in front of the Agency is also complicated, resulting in situation where the gathered data for Agency's work performance is connected to older court cases.

However, in order to understand the trail of the confiscated assets and in more to understand the possibility of future social reuse of the confiscated assets it is not necessarily important to evaluate the court's performance in the implementation of the confiscation. Instead of this it is more important to analyse the practice of the Agency for Management of the confiscated assets in order to evaluate whether the confiscated assets can be used for future legally acceptable purposes. Instead, our data was gathered through the official request for information submitted to the Agency.

Due to these reasons, for the purpose of the writing of this article we have contacted the Agency for Management of the Confiscated Assets in order to receive formal information in regard to the epilogue of the confiscated assets as performed by the Agency.

\begin{tabular}{|c|c|c|c|c|}
\hline \multicolumn{5}{|c|}{ TOTAL INCOME FROM THE SALE OF CONFISCATED AND SEIZED ASSETS } \\
\hline 2016 & 2017 & 2018 & 2019 & 2020 \\
\hline $1.982 .686 \mathrm{EUR}$ & $630.281 \mathrm{EUR}$ & $1.813 .590 \mathrm{EUR}$ & $9.289 .672 \mathrm{EUR}$ & $807.720 \mathrm{EUR}$ \\
\hline
\end{tabular}

Table: Data from Agency for Management of the Confiscated Assets - Total Income from selling of the assets

The Agency for Management of the Confiscated Assets have generously provided an answer to our request and provided us a data for the total income received from selling of the confiscated assets, together with the data for possible transfer of the confiscated assets and forfeited goods to other state institutions and data 
for transferred confiscated vehicles. ${ }^{26}$ Unfortunately, from the data gathered from the Agency, we have learned that the Agency does not have further tracking of the transferred assets and is not aware whether and to whom (legal entity or natural persons) these assets are transferred. On the other hand, the Agency have records of the state institutions and state bodies that have received the transferred confiscated motor vehicles.

From the data gathered from the Agency we can conclude that other than these amounts that were gained as an income from the selling of the confiscated and seized assets, the Agency has also transferred assets predominantly to the Ministry of Labour and Social Welfare. These transfers due to the limitations of the Law are not considered as a social reuse, despite the fact that in most of the cases these transfers could be annotated as such social reuse. Hence, usually confiscated vehicles are generally transferred to state bodies and institutions that can be considered in some hand as a social reuse.

From the available data we can learn that the Agency has donated various confiscated and seized goods to the Ministry in amount of $183.000,00$ euros in 2019, while in 2020 these donated goods were in value of 148.500,00 euros. Regarding the transferred vehicles, from the data gathered from the Agency we can understand that in the period of 2017 till 2020 approximately $135^{27}$ vehicles per year were transferred to the state bodies and institutions in estimated value of approximately 480.000,00 euros per year.

Connecting these numbers with the data from the courts in regard to the number of court cases where these measures were imposed, we can conclude that despite the relatively small number of cases where the courts have imposed such measures, these measures provide substantial income to the Macedonian state budget.

However, in regard to the social reuse of the confiscation, we can conclude that there are several obvious gaps in order to improve its implementation. First and the most important reason lays upon the legal imperfection, since the Law on Management of Confiscated Assets does not provide any legal grounds for actual

26 The data was gathered trough official request submitted to the Agency in order to use publicly shared information from the Agency on the International online workshop "Addressing Organized Crime and Corruption through the Re-use of Confiscated Criminal Assets" Organized by OSCE, on 10-th of December, 2020 presented, by the Senior Advisor in the Agency for Management of the Confiscated Assets in Republic of North Macedonia.

27 From the data gathered from the Agency for Management of Confiscated Assets we can learn that in 2020 a 150 vehicles were transferred in value of 510.569,00 euros; in 2019 the number of transferred vehicles is 141 in value of 438.019,00 euros; in 2018, a 138 vehicles were transferred in value of 530.349,00 euros, while in 2017 the number of transferred vehicles is 107 in value of $410.746,00$ euros. 
transfer of such assets to a NGO's or social vulnerable groups as a direct transfer for immediate social reuse of such goods. Hence, despite the fact that there is probably transfer of these goods to such groups through the Ministry of Labour and Social Welfare, we cannot have clear tracking, nor we can discuss the proper social reuse doctrine of the confiscated assets.

Proper addressing into the media and professional public is another thing that seems to be missing in order to elaborate the necessity of confiscation of assets and its social benefit. Through such initiatives the general public can become aware upon the activities of the Agency, which should pave the road into the increase of the level of trust of the functioning of the criminal justice system. Due to these limitations, the general public usually has the impression that the Criminal Justice system in North Macedonia has poor performance record in the "battle" with the criminals in regard to the confiscation of their criminal gain.

Contrary to this general perception, we are witnessing that, although severely understaffed, the Agency produces substantial income to the Macedonian economy and successfully cope with the challenges connected with the management of the confiscated assets. However, the above numbers, should not be considered as a satisfactory answer towards the fight and suppression of the crime in Republic of North Macedonia, but instead, the above mentioned numbers and figures should serve to as only a tool for motivation. Since with such low number of imposed measures for confiscation of assets or measures for forfeiture of the instrumentalities of the crime (corpora delicti), the state can gain substantial economic wealth. We should work upon finding further possibilities for expanding such activities by the courts and all others members from the law enforcement authorities.

\subsection{Potential for adoption of social reuse by the Republic of North Macedonia}

Despite the fact that there are limited number of ongoing academic and professional debates regarding the possibility of introduction of social reuse of the confiscated assets in Republic of North Macedonia, we deem that the Agency for Management of the Confiscated Assets has already paved the road towards its proper implementation. Hence, from the above mentioned data gathered from the Agency, we can witness that the culture of sharing and giving of the confiscated assets from the state organs to the institutions appears to be acceptable practice.

In order to improve such practise there are at least two or even more possible fronts that should simultaneously develop. First one is the reform and upgrading of the Law on Management of Confiscated Assets; second one is changes of the stakeholders' mentality trough public campaigns for raising awareness of social 
reuse of confiscated assets; the third one is further support to the Agency trough financial and manpower aid; while other front is strengthening the legal culture and reform of the law enforcement agencies where these agencies would be focused not only upon the crime stopping, but also towards the investigation of the illegal financial flows.

Initially and obviously the Law on Management of Confiscated Assets, needs to be reform into the sense where it will allow the Agency to develop social reuse strategies for the confiscated assets. This front seems to be the easiest task, since it requires only legislative amendments that can be drafted and implemented into the Law. Considering the Law on Management of Confiscated Assets there are obvious further needs for improvement, since the law in many cases is unclear, has several legal lacunas and do not answer the modern needs of the Agency. The most problematic and urgent issues in this Law are: obsolete or limited types of disposal of the assets; need for introduction of registry of the confiscated and forfeited assets; necessity for improvement of the provisions for procedure for selling of these assets and improvement of the possibilities for direct transfer of part of the profits gain from the disposal of the confiscated assets to the Agency as necessity for its proper function and future development.

In regard to the raising of the public awareness, towards the social reuse of the confiscated assets, we deem that is necessary initially to establish good practice of regularly inform the public of the activities of the Agency. This should be done by updating of the Agency web site on regular basis, and together with raising media campaigns where the general public would be informed of the "successful stories" from the social reuse of the confiscated assets. State bodies should change the climate where the judges and prosecutors would not have any further insight whether the confiscated asset is sold, destroyed, mixed or reused in any other way $^{28}$, as a result of their daily activities at a courtroom. Knowing these particular information regarding the criminally gained assets, the judges and prosecutors might double their efforts into the search and confiscation of such assets within their practice.

Finally, increased implementation of confiscation or improvement of this tool via the introduction of several models for the social reuse of these assets will increase the efficiency of the criminal justice system. It could in fact provide criminal justice actors, particularly judges, with a clear vision of where confiscated assets where used for, as well as with a better understanding of the societal benefit from

28 See: Vettori B.; Misoski B., "Social Reuse of Confiscated Assets in the EU: Current Experiences and Potential for its Adoption by Other EU and non-EU Countries", Collection of Papers in Honour of Akad. Vlado Kambovski, Macedonian Academy of Arts and Sciences (MASA), 2019. 
their work. This fact should endow judges and other law enforcement agencies to put additional effort in investigating the proceeds from crime and ultimately to use confiscation more frequently. A second benefit would be through the fact that the message will be sent to the criminals that in most of the cases crime will not pay, which might be detrimental for undertaking future criminal activities. ${ }^{29}$

Hence, legal amendments to the Law on Criminal Procedure and Law on Public Prosecution in a way of fostering the establishment of the Investigative Centres and further support and strengthening of the Financial Police and Public Prosecution Offices with financial aids together with the adequately staffing with prosecutors and investigators. Such improvements of these state bodies would result into frequent commencement of thorough financial investigations as essential part of the criminal investigations and would increase the coordination between the abovementioned state agencies. Only through such improvements of these state bodies we could expect increase of the number of confiscated and forfeited assets, which would finally lead towards the increased implementation of the social reuse of such assets.

Last, but not less important is the further support to the Agency with financial and manpower aid. This means that if the employees of the Agency has sufficient financial assets and well trained staff, than, by all means, we should expect increase of its effectiveness and efficiency into the management of the confiscated and forfeited assets.

\section{CONCLUSION}

Social reuse of the confiscated assets seems to be the future "big deal" of the management of confiscated assets. This is based upon the fact that trough such management the direct message is sent to the public that convicted criminals does not gain from the crime and that their criminal gain is feasibly and transparently transferred to the members of the community. However, in order to have effective social reuse of the confiscated assets several preconditions need to be met, such as efficient Agency for Management of the confiscated assets based upon proper legal basis for implementation of the social reuse procedures. Hence forward, in order to have proper management of the confiscated assets we need operational Agency that takes proper care of such assets that can be further either transferred to the community or sold on public auctions. One of the most important tools

29 See: Misoski B., The Impact of the EU Directive 2014/42/EU on Freezing and Confiscation of Instrumentalities and Proceeds of Crime to the Macedonian Criminal Justice System, in: Petrašević, T.; Duić, D. (eds.), EU Law in Context - Adjustment to Membership and Challenges of the Enlargement, Vol. 2, Faculty of Law Osijek, Croatia, 2018, p. 371. 
for proper management of such assets seems to be the organization of databases for the confiscated assets where every confiscated and seized item will be properly marked and tracked by the Agency in order to determine the most suitable type of management of such assets. Functional databases will provide proper ground for reduction of depreciation of the value of the confiscated assets. These novelties already present on several EU member states' soil, although recognized by the Macedonian legislator, seems to be routed on the waiting list for their enactment by the Parliament and operationalized in practice by the Agency for management of the confiscated assets.

\section{REFERENCES}

\section{BOOKS AND ARTICLES}

1. FATF, Best Practices Paper. Best practices on confiscation (recommendations 4 and 38) and a framework for ongoing work on asset recovery, FATF/OECD, Paris, October 2012

2. G8 Lyon/Roma Group Criminal Legal Affairs Subgroup, G8 Best Practices for the Administration of Seized Assets, 27 April 2005

3. Misoski B.; Petrovska N.; Avramovski D., "Analysis of Data Obtained from Monitoring Court Proceedings within the Field of Organized Crime and Corruption in 2019", Coalition All for Fair Trials, OSCE Mission to Skopje, 2020

4. Misoski B., "The Impact of the EU Directive 2014/42/EU on Freezing and Confiscation of Instrumentalities and Proceeds of Crime to the Macedonian Criminal Justice System", in Petrašević, T.; Duić, D. (eds.), EU Law in Context - Adjustment to Membership and Challenges of the Enlargement, Vol. 2, Faculty of Law Osijek, Croatia, 2018

5. Vettori B., "The disposal of confiscated assets in the EU Member States: what works, what does not work and what is promising”, in: King, C.; Walker, C.; Gurulé, J. (eds.), The Palgrave handbook of criminal and terrorism financing law, volume 1, Palgrave Macmillan, Basingstoke, 2018, pp. 705-733

6. Vettori B.; Misoski B., "Social Reuse of Confiscated Assets in the EU: Current Experiences and Potential for its Adoption by Other EU and non-EU Countries", Collection of Papers in Honour of Akad. Vlado Kambovski, Macedonian Academy of Arts and Sciences (MASA), 2019

\section{EU LAW}

1. European Commission, Report from the Commission to the European Parliament and the Council "Asset recovery and confiscation: Ensuring that crime does not pay", Brussels, 2 June 2020, $\operatorname{COM}(2020) 217$ final

\section{LIST OF NATIONAL REGULATIONS, ANCT AND COURT DECISIONS}

1. Law on Management of Confiscated Assets, Official Gazette of the Republic of Macedonia No. 98/2008, 145/2010, 104/2013, 187/2013, 43/2014, 160/2014, 97/2015, 148/2015 and $64 / 2018$. 
2. 1924 English case $R v$ Sussex Justices, Ex Parte McCarthy.

\section{WEBSITE REFERENCES}

1. Organización de los Estados Americanos, Analysis of Systems for the Collection of Data on Seized and Forfeited Assets of Illicit Origin in the Member States of the OAS, 2014, available at [http://cicad.oas.org/apps/document.aspx?id=2978], Accessed June 10, 2021

2. [http://www.merc.org.mk/aktivnost/48/dijalog-za-politika-konfiskacija-na-imot-i-nelegalno-steknata-imotna-korist], Accessed June 10, 2021

3. Avramovski D.; Petrovska N., Confiscation of Assets in the Corruption Cases, CAFT, 2019 (in Macedonian), available at [PB-CAFT-MKD-2019.pdf], [all4fairtrials.org.mk], Accessed June 10, 2021

4. Organización de los Estados Americanos, Asset Management Systems in Latin America and Best Practices Document on Management of Seized and Forfeited Assets, 2011, available at [http://www.cicad.oas.org/lavado_activos/grupoExpertos/Decomiso\%20y\%20ED/Manual\%20Bienes\%20Decomisados\%20-\%20BIDAL.pdf], Accessed June 10, 2021

5. UNODC, Effective management and disposal of seized and confiscated assets, UNODC, Vienna, 2017, available at [https://www.unodc.org/documents/corruption/Publications/2017/17-07000_ebook_sr.pdf], Accessed June 10, 2021

6. [http://www.vsrm.mk/wps/portal/osskopje1/], Accessed June 10, 2021

7. [http://www.bamin-network.org/], Accessed June 10, 2021

8. [https://www.cashbackforcommunities.org/], Accessed June 10, 2021

9. [www.jorm.gov.mk], Accessed June 10, 2021

10. [www.odzemenimot.gov.mk], Accessed June 10, 2021

11. [www.stat.gov.mk], Accessed June 10, 2021 